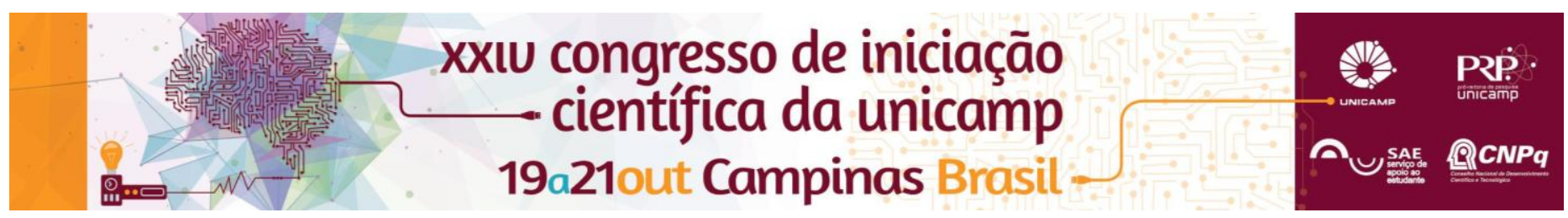

\title{
Aditivos de biodiesel para melhoramento do ponto de entupimento de filtro a frio.
}

\author{
Matheus L. Romero*, Willian L. G. Silva, Matthieu Tubino.
}

\section{Resumo}

Neste trabalho foi sintetizado biodiesel a partir de óleo de soja por reação de transesterificação. Posteriormente foram adicionados terpenos como aditivos a fim estudar a sua influência no ponto de entupimento do filtro a frio (PEFF). Em baixas temperaturas, o biodiesel tende a perder sua fluidez, causando entupimento de filtros de motores causando a interrupção do seu funcionamento. O uso de terpenos e de líquido da castanha de cajú (LCC) visa diminuir o ponto de entupimento do filtro a frio.

\section{Palavras-chave:}

Biodiesel, Terpenos, Aditivos.

\section{Introdução}

O biodiesel é um biocombustível, constituído por uma mistura de ésteres graxos obtidos por reação de transesterificação entre um óleo vegetal ou gordura animal e um álcool na presença de um catalisador ${ }^{1}$. O biocombustível gerado apresenta propriedades físicas e químicas que são parecidas com as do diesel do petróleo, podendo assim ser utilizado em motores na forma de misturas diesel/biodiesel.

Uma característica importante é o ponto de entupimento de filtro a frio (PEFF), que é a temperatura na qual o fluxo de biodiesel, através de um filtro, é interrompido. Altos valores de ponto de entupimento podem levar a obstrução de filtros de motor, ocasionando problemas de funcionamento. A temperatura máxima de PEFF permitida no Brasil é de $9{ }^{\circ} \mathrm{C}$ segundo a Agência Nacional do Petróleo, Gás Natural e Biocombustíveis $(\mathrm{ANP})^{2}$

Terpenos são moléculas constituídas por unidades básicas de isopreno, muito utilizados na fabricação de fragâncias e solventes, além de possuírem propriedades medicinais $^{3}$ e inseticidas, e que devido à pouca demanda, o Brasil tem capacidade de utilizá-los como aditivos em biodiesel.

O principal objetivo do trabalho é diminuir o valor de ponto de entupimento de filtro a frio do biodiesel através da adição de terpenos e de líquido da castanha de caju.

\section{Resultados e Discussão}

Para este trabalho, foi sintetizado aproximadamente meio litro de biodiesel metílico de soja, misturando ao óleo de soja metanol e metóxido de sódio, usado como catalisador, correspondendo a $16 \%$ e 0,56 \% da massa do óleo, respectivamente. A mistura reacional foi mantida por uma hora sob refluxo, agitação de $900 \mathrm{rpm}$ e aquecimento a $60^{\circ} \mathrm{C}$. Após esse período foi retirado o glicerol formado e seguiu-se a segunda etapa da reação com adição de mais metanol e catalisador correspondentes a $4 \%$ e $0,14 \%$ da massa inicial do óleo respectivamente. Na sequência, o biodiesel produzido foi submetido a processos de purificação que consistem em lavagem com água, secagem em estufa a $100^{\circ} \mathrm{C}$ e percolação em resina de troca iônica Amberlite $B D 10$ DRY.

Depois de preparado do biodiesel, foram feitas as análises do PEFF do biodiesel puro e aditivado com líquido da castanha de caju (LCC), terebentina, óleo de pinho e mistura de terpenos X1200, sendo estes aditivos correspondentes a $0,5 \% \mathrm{~m} / \mathrm{m}$ em relação ao biodiesel. As medidas foram feitas em triplicata.

Os resultados do PEFF do biodiesel puro e aditivado estão mostrados na Figura 1.

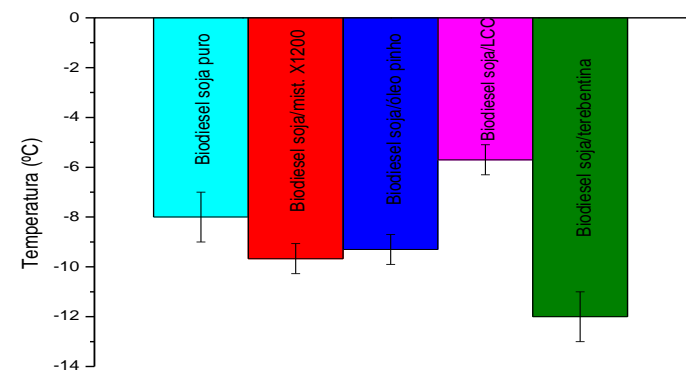

Figura 1. Valor do PEFF dos biodieseis puros e aditivados.

Observa-se que a adição dos terpenos, mistura X1200, óleo de pinho e terebentina, causaram redução do PEFF do biodiesel de soja.

A adição de terebentina causou a maior redução de temperatura dentre os terpenos estudados, cerca de $4 \stackrel{\circ}{\circ}$. O LCC não se mostrou um aditivo eficiente para redução do PEFF, apesar de estudos mostrarem sua contribuição como antioxidante de biodiesel ${ }^{4}$.

\section{Conclusões}

A adição de terpenos ao biodiesel metílico de soja causou diminuição dos valores de PEFF sendo a terebentina o terpeno mais efetivo com redução de $4 \stackrel{\circ}{\circ} \mathrm{C}$, o que possibilita o uso desse biocombustível em regiões com climas mais frios.

\section{Agradecimentos}

\section{Ao CNPq e ao IQ-UNICAMP pela infraestrutura.}

\footnotetext{
${ }^{1}$ Marques, M.V.; Naciuk, F.F.; Melo, A.M.S.; Seibel, N.M.; Fontoura L.A.M., Quim. Nova, 2010, 33, 4;

${ }^{2}$ BRASIL, ANP. Agência Nacional do Petróleo, Gás Natural e Biocombustíveis. Resolução ANP nº 45,de 22 de agosto de 2014

${ }^{3}$ Onuki, J.; Teixeira, P.C.; Medeiros, M.H.G.; DiMascio, P., Quím. Nova, 2002 25,4 .

${ }^{4}$ Bastos, F.A.; Tese de doutorado Unicamp, Campinas 2014
} 